\title{
High-Activity Mesoporous Pt/Ru Catalysts for Methanol Oxidation
}

\author{
Esteban A. Franceschini, ${ }^{\dagger}$ Mariano M. Bruno, ${ }^{\dagger, \dagger}$ Federico J. Williams, ${ }^{\S}$ Federico A. Viva, ${ }^{\dagger}$ \\ and Horacio R. Corti ${ }^{*},, \S$ \\ ${ }^{\dagger}$ Grupo de Celdas de Combustible, Departamento de Física de la Materia Condensada, Centro Atómico Constituyentes, CNEA. \\ 1650, Buenos Aires, Argentina. \\ \# Escuela de Ciencia y Tecnología, Universidad de Gral. San Martín, 1650, Buenos Aires, Argentina \\ ${ }^{\S}$ Departamento de Química Inorgánica, Analítica y Química-Física, INQUIMAE CONICET, Facultad Ciencias Exactas y Naturales, \\ Pabellón 2, Ciudad Universitaria, Buenos Aires, Argentina
}

\begin{abstract}
High activity mesoporous $\mathrm{Pt} / \mathrm{Ru}$ catalysts with 2D-hexagonal structure were synthesized using a triblock poly(ethylene oxide)- $b$-poly(propylene oxide)- $b$-poly(ethylene oxide) copolymer (Pluronic F127) template. The normalized mass activities for the methanol oxidation reaction (MOR) of the $\mathrm{Pt} / \mathrm{Ru}$ catalysts with a regular array of pores is higher than those reported for nanoparticulated $\mathrm{Pt} / \mathrm{Ru}$ catalysts. Different kinetic parameters, as Tafel slope and activation energy, were obtained for the MOR on the mesoporous catalysts. Results indicated that catalysts performance depends on pore size. Mass activities and the $\mathrm{CO}_{2}$ conversion efficiency for large pore size mesoporous catalysts $(10 \mathrm{~nm})$ are greater than those reported for smaller pore size mesoporous catalysts with similar composition. The effect of pore size on catalysts performance is related to the greater accessibility of methanol to the active areas inside large pores. Consequently, the overall residence time of methanol increases as compared with mesoporous catalyst with small pores.
\end{abstract}

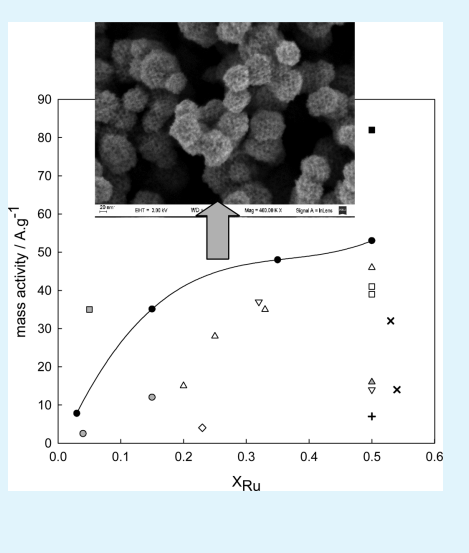

KEYWORDS: fuel cells, methanol, Pt/Ru catalysts, mesoporous, mass activity, PluronicF127

\section{INTRODUCTION}

Catalysts for direct methanol proton exchange membrane (DMPEM) micro fuel cells based on $\mathrm{Pt}$ and $\mathrm{Pt} / \mathrm{Ru}$ alloys have been developed using a number of electrodeposition techniques, ${ }^{1,2}$ allowing the integration of components (catalysts and gas diffusion layers) and reducing the contact resistance of the assembly. Furthermore, metal films with a well-defined periodic mesoporous nanostructure, which can be obtained by reduction of metallic precursors dissolved in the aqueous domains of the liquid crystalline phases of surfactants, can also be used as efficient catalysts. ${ }^{3-8}$ These mesoporous catalyst materials exhibit a hexagonally ordered regular array of open pores with high surface areas. ${ }^{9-11}$

In DMFC, mass transport can be hindered by the occlusion of $\mathrm{CO}_{2}$ bubbles inside the pores, which decreases the electrocatalytic performance by blocking the catalyst surface. In addition, different reports ${ }^{12-14}$ indicate that there should be an optimal pore size to maximize transport processes. Consequently catalytic performance of DMFC can be improved by tuning mesoporous catalyst pore size.

We previously reported that a mesoporous $\mathrm{Pt}_{0.97} \mathrm{Ru}_{0.03}$ catalyst exhibited higher mass activities and current densities for the methanol oxidation reaction (MOR) than a mesoporous catalyst of similar composition with smaller pore diameter $(2.5-3 \mathrm{~nm}){ }^{15}$

In this work, we study the performance of mesoporous $\mathrm{Pt} /$ $\mathrm{Ru}$ catalysts with different $\mathrm{Pt} / \mathrm{Ru}$ ratios for the MOR. The catalysts with hexagonal $2 \mathrm{D}$ pore array ${ }^{15,16}$ were synthesized by electrodeposition of $\mathrm{Pt}$ and $\mathrm{Ru}$ precursors mixtures over a gold substrate, using Pluronic F127 as a nanostructured template. The "cavity-crystals", obtained with this template, allows the formation of large pore size $(\sim 10 \mathrm{~nm})$ mesoporous materials as oppose to their analogues derived from low molecular weight surfactants (i.e., pore size $\sim 2.5 \mathrm{~nm}$ ). ${ }^{17-20}$

The goal of this work is to develop high-performance anodes for micro direct methanol fuel cells ( $\mu$ DMFC) for powering or charging portable electronic devices, i.e., mobile phones, mp3, tablets, etc. Our results for $\mathrm{Pt}_{x} \mathrm{Ru}_{1-x}$ catalysts, with compositions ranging from $x=0.50$ to $x=0.97$, were compared with those reported for mesoporous $\mathrm{Pt} / \mathrm{Ru}$ catalysts with smaller pore size, and with nanoparticulated $\mathrm{Pt} / \mathrm{Ru}$ catalysts supported on Vulcan, ${ }^{3,21}$ mesoporous carbon, ${ }^{22}$ and $\mathrm{CNT}^{23}$ of similar composition.

\section{EXPERIMENTAL SECTION}

2.1. Chemicals. Hydrated hexachloroplatinic acid (HCPA, 99.99\%, Aldrich), ruthenium trichloride (99.99\%, Aldrich), triblock $\mathrm{EO}_{106} \mathrm{PO}_{70} \mathrm{EO}_{106}$ copolymer, denoted Pluronic F127 $\left(M_{\mathrm{w}}=12600\right.$, Aldrich), methanol (99.8\%, Research S.A.) and sulfuric acid (PA grade, Research S.A.) were used as received. Solutions were prepared with deionized water (resistivity $\approx 18 \mathrm{M} \Omega \mathrm{cm}$ ), degassed using high-purity $\mathrm{N}_{2}$ (Indura S.A.). Commercial $\mathrm{Pt}_{0.50} \mathrm{Ru}_{0.50} / \mathrm{C}$ catalyst (E-TEK, $20 \mathrm{wt} \%$ Pt load) was used for control analysis. High-purity CO (Indura S.A.) gas was used for the determination of the electrochemical surface area.

Received: December 18, 2012

Accepted: October 1, 2013

Published: October 1, 2013 
2.2. Catalysts Synthesis. The precursor solutions were prepared by mixing different volumes of $0.1 \mathrm{M} \mathrm{HCPA}$ and $0.2 \mathrm{M} \mathrm{RuCl}_{3}$ to obtain different nominal compositions. Viscous mixtures were prepared by mixing $1 \mathrm{~g}$ of Pluronic F127 and $1 \mathrm{~cm}^{3}$ of metal precursor solutions.

Metal precursors mixtures were poured in a purpose-built threeelectrode electrochemical cell with a gold working electrode, a platinum counter electrode with a large surface area, and a $\mathrm{Ag} / \mathrm{AgCl}$ (sat) reference electrode. The last electrode was inserted in the mixture between the working and the counter electrode. The catalysts synthesis was carried out by reducing the precursor metals at a current density of $0.4 \mathrm{~mA} \mathrm{~cm}^{-2}$ during 30 minutes at room temperature. ${ }^{15}$ The mass of the electrodeposited catalyst on the gold substrate was determined by employing a microbalance (Mettler XP2U).

The electrodes used for chronoamperometry, cyclic voltammetry, structural, and composition characterizations were electrodeposited over gold slide electrodes (EMF Company). The electrodes used for differential electrochemical mass spectroscopy (DEMS) analysis were electrodeposited over a gold disk (area: $0.283 \mathrm{~cm}^{2}$ ) with a circular hole (0.1 $\mathrm{mm}$ in diameter). This allows the reactant flow during the measurement.

2.3. Structure and Composition. The STM images were acquired with a Veeco DI Multimode Nanoscope IIIa, with $10 \mu \mathrm{m}$ lateral scan range and a $2 \mu \mathrm{m} \mathrm{z}$-scanner. The bias potential was $10 \mathrm{mV}$ and the tunneling current was fixed at $1 \mathrm{nA}$, using a Pt/Ir tip (Nano Devices, Veeco Metrology, Santa Barbara, CA).

Scanning electron micrographs were obtained using a Supra 40 (Zeiss Company) FESEM operating at $3 \mathrm{kV}$ and equipped with an Oxford EDX.

X-ray Photoelectron Spectroscopy measurements (XPS) were performed under UHV conditions (base pressure $<5 \times 10^{-10}$ mbar) in a SPECS UHV spectrometer system equipped with a 150 $\mathrm{mm}$ mean radius hemispherical electron energy analyzer and a nine channeltron detector. XPS spectra were acquired at a constant pass energy of $20 \mathrm{eV}$ using an un-monochromated $\mathrm{MgK} \alpha(1253.6 \mathrm{eV})$ source operated at $12.5 \mathrm{kV}$ and $20 \mathrm{~mA}$, and a detection angle of $30^{\circ}$ with respect to the sample normal on grounded conducting substrates. Quoted binding energies are referred to the adventitious C 1 s emission at $285 \mathrm{eV}$. Atomic ratios and surface concentrations were calculated from the integrated intensities of core levels after instrumental and photoionization cross-section corrections.

Powder X-ray diffraction (PXRD) patterns were obtained with a SIEMENS D-5000 instrument, employing Ni-filtered $\mathrm{Cu} K_{\text {alfa }}$ radiation. PXRD patterns were recorded between $30-90^{\circ}$, set at $0.02^{\circ}$ step size and a $4 \mathrm{~s}$ step time, and the pattern displacements were corrected using the peaks of a gold substrate as reference. Pt diffraction peaks were deconvoluted from the substrate ones by means of profile fitting software.

2.4. Electrochemical Characterization. 2.4.1. Electrochemical Cells and Instruments. All electrochemical experiments were performed with an Autolab PGSTAT302N potentiostat (Echochemie, Netherlands). $\mathrm{Ag} / \mathrm{AgCl}$ (sat) reference electrodes were used in the electrochemical experiments. However, all the reported potentials were referred to the reversible hydrogen electrode (RHE). The counter electrode was a large area coiled platinum wire $(0.5 \mathrm{~mm}$ in diameter, $30 \mathrm{~cm}$ length). A conventional three electrodes electrochemical cell with thermostatic jacket was used in all the experiments. The temperature of the cell was controlled using a Techne thermostat. Purpose built three electrodes electrochemical cells were used in the mesoporous catalyst preparation and DEMS analysis. ${ }^{15,24,25}$

2.4.2. Electrochemical Surface Area (ECSA). $\mathrm{H}_{2}$ adsorption measurements could lead to errors due to the formation of ruthenium oxides on $\mathrm{Pt} / \mathrm{Ru}$ alloy catalysts. ${ }^{23,26,27}$ Therefore, $\mathrm{CO}$ voltammetric stripping experiments were performed in order to obtain the Electrochemical Surface Area (CO-ECSA). The experiments were carried out adsorbing $\mathrm{CO}$ onto the electrode surface by bubbling high purity $\mathrm{CO}$ through $0.5 \mathrm{M} \mathrm{H}_{2} \mathrm{SO}_{4}$ solution; the electrode potential was set at $250 \mathrm{mV}$ vs RHE. After an adsorption period of approximately 1 $\mathrm{h}$, the dissolved $\mathrm{CO}$ was removed from the solution by bubbling high purity nitrogen for $15 \mathrm{~min}$, whereas maintaining the potential at 250
$\mathrm{mV}$. The potential was then scanned at $1 \mathrm{mV} \mathrm{s}^{-1}$ in the positive-going direction between 90 and $800 \mathrm{mV}$ (vs RHE). The charge determined for the same electrode in the absence of the adsorbed $\mathrm{CO}$ was subtracted from the total charge in order to correct the effects of oxide growth and double layer. ${ }^{26}$

Cyclic voltammetric measurements were also carried out in $0.5 \mathrm{M}$ $\mathrm{H}_{2} \mathrm{SO}_{4}$, at $25{ }^{\circ} \mathrm{C}$, to analyze the hydrogen adsorption/desorption peaks areas (H-ECSA), and to compare them with CO-ECSA. HECSA values were determined by considering that the charge involved in a one electron reaction per surface $\mathrm{Pt}$ atom, assuming linear configuration of adsorption and full coverage, is $210 \mu \mathrm{C} \mathrm{cm}^{-2}$. ${ }^{28}$ Thus, $\mathrm{ECSA}=Q /(n \cdot 210)$, where $Q($ in $\mu \mathrm{C})$ is the charge transferred during the cyclic voltammetric experiment, and $n$ is the number of electrons exchanged in the reaction $\left(n=2\right.$, for the $\mathrm{CO}$ to $\mathrm{CO}_{2}$ reaction, and $n=$ 1 for the $\mathrm{H}_{2}$ adsorption/desorption).

2.4.3. Methanol Oxidation Analysis. Methanol electro-oxidation experiments were performed in $0.5 \mathrm{M} \mathrm{H}_{2} \mathrm{SO}_{4} / 1.0 \mathrm{M}$ methanol solutions purged with nitrogen. Chronoamperometric profiles were measured by applying a step potential from 244 to $644 \mathrm{mV}$ (vs RHE) and recording the current transient for $2 \mathrm{~h} .{ }^{15}$ Cyclic voltammetries were performed at scan rates between 5 and $25 \mathrm{mV} \mathrm{s}^{-1}$, from 0 to 800 $\mathrm{mV}$ (vs RHE), at temperatures between 10 and $45^{\circ} \mathrm{C}$. Tafel analysis was performed at $25^{\circ} \mathrm{C}$.

DEMS analysis in methanol solution was conducted to obtain the methanol to $\mathrm{CO}_{2}(\mathrm{~m} / z=44)$ conversion efficiency at $25^{\circ} \mathrm{C}$. The flow rate $\left(0.15 \mathrm{~cm}^{3} \mathrm{~min}^{-1}\right)$ through the cell was controlled by the hydrostatic pressure of the electrolyte in the reservoir using a twochamber flow system.

The calculation of the efficiency for methanol conversion to $\mathrm{CO}_{2}$ requires the determination of the $\mathrm{m} / z=44$ calibration constant, $K(44)$, by means of a procedure described in detail elsewhere, ${ }^{29-32}$ which involves the measurement of the Faradaic charge, $\mathrm{Q}_{\mathrm{F}}^{\mathrm{CO}}$, corresponding to the oxidation of $\mathrm{CO}$ to $\mathrm{CO}_{2}$. The $\mathrm{CO}$ voltammetric stripping experiments were performed in $0.5 \mathrm{M} \mathrm{H}_{2} \mathrm{SO}_{4}$ solution at 25 ${ }^{\circ} \mathrm{C}$ maintaining the electrode potential at $250 \mathrm{mV}$ (vsRHE) during $1 \mathrm{~h}$. The potential was then scanned at a rate of 1 and $5 \mathrm{mV} \mathrm{s}^{-1}$ between 50 and $850 \mathrm{mV}$ (vsRHE) in the positive-going direction. K(44) was calculated through the expression

$$
K(44)=\frac{2 Q_{\mathrm{MS}}(44)}{Q_{\mathrm{F}}^{\mathrm{CO}}}
$$

where $Q_{\mathrm{MS}}(44)$ is the integrated mass spectrometric current for the two-electron electro-oxidation of $\mathrm{CO}$ to $\mathrm{CO}_{2}$.

The average efficiency of conversion of methanol to $\mathrm{CO}_{2}$ was calculated using the following equation ${ }^{33}$

$$
\eta_{\mathrm{Q}}=\frac{\mathrm{Q}_{\mathrm{F}}^{*}}{\mathrm{Q}_{\mathrm{F}}^{\mathrm{CH}_{3} \mathrm{OH}}}
$$

where $Q_{F}^{\mathrm{CH}_{3} \mathrm{OH}}$ is the total Faradaic charge (i.e., forward and reverse scan charge) and $Q_{F}^{*}$ is the Faradaic charge corresponding to the sixelectron oxidation of methanol to $\mathrm{CO}_{2}$, given by

$$
Q_{\mathrm{F}}^{*}=\frac{6 Q_{\mathrm{MS}}(44)}{K(44)}
$$

where $Q_{M S}(44)$ is the integrated mass spectrometric current of the $\mathrm{CO}_{2}$ generated by methanol oxidation and measured in one potential sweep cycle, as an average of the positive- and negative-going sweeps, over all the potential range. The differences between the conversion efficiencies calculated in each scan direction were small (ca. $7 \%$ ). Consequently, the errors of the averaged conversion efficiencies were also small.

$\mathrm{CO}$, formic acid, and formaldehyde cannot be directly quantified by DEMS because the fragmentation of methanol and $\mathrm{CO}_{2}$ (containing species with natural isotopes of carbon and oxygen) lead to intermediate products with mass signal that overlaps with those of formaldehyde $(\mathrm{m} / z=30)$, $\mathrm{CO}(\mathrm{m} / z=28)$, and formic acid $(\mathrm{m} / z=$ 46). Although the presence of formic acid is indirectly verified by the formation of methyl formate as observed in the MSCVs, it cannot be 
quantified with a simple calibration procedure similar to that performed for $\mathrm{CO}_{2}$

\section{RESULTS AND DISCUSSION}

A comprehensive morphological analysis of the mesoporous $\mathrm{Pt}_{x} \mathrm{Ru}_{1-x}$ catalysts and the electrochemical characterization for the MOR is described in this Section.

3.1. Structure and Composition. 3.1.1. FESEM. Figure 1 shows the SEM micrograph of a mesoporous $\mathrm{Pt}_{0.65} \mathrm{Ru}_{0.35}$

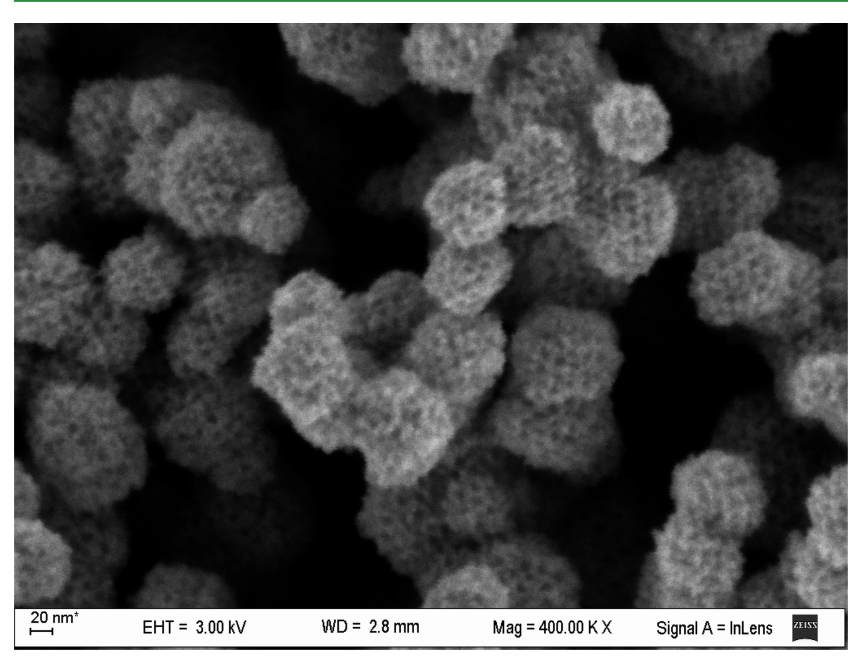

Figure 1. FESEM micrograph of $\mathrm{Pt}_{0.65} \mathrm{Ru}_{0.35}$ catalyst. Magnification: $400000 \times$.

catalyst evidencing a well-ordered pore structure. The catalysts with other compositions exhibited similar structures. The observed geometries and pore size are similar to those reported previously for catalysts synthesized by a similar procedure, where the porous arrays have hexagonal $2 \mathrm{D} p 6 \mathrm{~m}$ symmetry. ${ }^{15} \mathrm{It}$ can also be observed that the mesoporous catalyst is formed by porous spheres, with a pore diameter of $\sim 10 \mathrm{~nm}$ (measured directly from the SEM micrograph).

The atomic compositions of the catalysts, obtained by EDX analysis, are shown in Table 1 . No significant deviations were

Table 1. Composition (expressed as atom \%) of the Synthesized Catalysts Obtained by EDX and XPS, Compared with the Nominal Composition of the Electrodeposition Mixture

\begin{tabular}{|c|c|c|c|c|c|}
\hline \multicolumn{2}{|c|}{ nominal } & \multicolumn{2}{|c|}{ EDX } & \multicolumn{2}{|c|}{ XPS } \\
\hline $\mathrm{Pt}$ & $\mathrm{Ru}$ & $\mathrm{Pt}$ & $\mathrm{Ru}$ & $\mathrm{Pt}$ & $\mathrm{Ru}$ \\
\hline 83.33 & 17.66 & $97^{a}$ & $3^{a}$ & $97^{a}$ & $3^{a}$ \\
\hline 68.96 & 31.04 & 85 & 15 & 85 & 15 \\
\hline 45.46 & 54.54 & 65 & 35 & 64 & 36 \\
\hline 31.25 & 68.75 & 50 & 50 & no data & no data \\
\hline${ }^{a} \operatorname{Ref} 15$. & & & & & \\
\hline
\end{tabular}

found on different regions of the samples, and the measured $\mathrm{Ru}$ contents were systematically lower than the nominal composition of the precursor mixture. The Pt content observed in the electrodeposited alloys was higher than the expected from the composition of the precursor mixtures. This indicates that the electro-deposition process was not completely controlled as desired. Nevertheless, ruthenium content in the alloys increased monotonically with its content in the precursor mixtures.

3.1.2. STM. STM analysis was carried out in order to elucidate the structure of the electrodeposits at nanoscopic scale. STM image for the $\mathrm{Pt}_{0.85} \mathrm{Ru}_{0.15}$ catalyst is shown in Figure 2 (left), where it can be observed that the structure is formed by an array of spheres. The sectional view shown in Figure 2 (right) indicates a mean particle size of approximately $10 \mathrm{~nm}$, which agrees with interpore walls measured by SEM. All catalysts showed similar structures to that shown in Figure 2, and the observed structures are consistent with the one presented in a previous work. ${ }^{15}$

3.1.3. XPS. Surface compositions of mesoporous $\mathrm{Pt} / \mathrm{Ru}$ alloys were determined by XPS, confirming the absence of metallic impurities. Figure 3a shows the Pt $4 \mathrm{f} \mathrm{XP}$ spectra of mesoporous $\mathrm{Pt}_{0.85} \mathrm{Ru}_{0.15}$ alloy catalyst. All the catalysts present doublets with binding energies of $71.2 \mathrm{eV}\left(\mathrm{Pt} 4 \mathrm{f}_{7 / 2}\right)$ and 74.5 $\mathrm{eV}\left(\mathrm{Pt} 4 \mathrm{f}_{5 / 2}\right)$, which are indicative of metallic Pt. Figure $3 \mathrm{~b}$ shows the corresponding $\mathrm{Ru} 3 \mathrm{p}_{3 / 2} \mathrm{XP}$ spectra of mesoporous $\mathrm{Pt}_{85} \mathrm{Ru}_{15}$ alloy catalyst with a binding energy of $462 \mathrm{eV}$. The surface composition estimated from the integrated $\mathrm{Pt} 4 \mathrm{f}$ and $\mathrm{Ru}$ $3 \mathrm{p}_{3 / 2}$ XP intensities are presented in Table 1 along with the composition obtained by EDX for the bulk catalysts. The fact that the compositions estimated by EDX and XPS are very similar indicates the absence of ruthenium segregation, resulting in a catalyst with homogeneous composition.

The presence of $\mathrm{Pt}$ oxides, expected at binding energies greater than $72 \mathrm{eV}$, was quantified and reported in Table 2 . It can be seen that, for all the catalysts, more than $85 \%$ of the platinum is present as a metal. In the case of ruthenium, the $3 p_{3 / 2}$ XP spectra is consistent with the presence of oxides. In order to quantify them, the spectra were fitted with three components ascribed to $\mathrm{Ru}\left(\mathrm{BE} 3 \mathrm{p}_{3 / 2}=461.8 \mathrm{eV}\right), \mathrm{RuO}_{2}(\mathrm{BE}$ $\left.3 \mathrm{p}_{3 / 2}=464.8 \mathrm{eV}\right)$ and $\mathrm{RuO}_{x} \mathrm{H}_{y}\left(\mathrm{BE} 3 \mathrm{p}_{3 / 2}=467.3 \mathrm{eV}\right)$, respectively. From the integrated areas of the three components, the compositions of ruthenium in the three different oxidation states were calculated for the different catalysts, as shown in Table 2 . This table shows that all the catalysts have 15 to $20 \%$ (atomic) $\mathrm{RuO}_{2}$, while the amount of $\mathrm{RuO}_{x} \mathrm{H}_{y}$ varies in the range $10-15 \%$, with most of the ruthenium in the metallic state.

In summary, the results agree with previous studies indicating that platinum in PtRu catalysts alloys is present almost entirely as a metal with a small portion in oxidized form. Ruthenium, because of its lower oxidation potential, ${ }^{34,35}$ is essentially present as the oxidized form.

3.1.4. XRD. The X-ray diffractograms of different mesoporous $\mathrm{Pt} / \mathrm{Ru}$ alloys catalysts were obtained. The alloys phase cell parameters and average crystal size calculated using Scherrer's equation, ${ }^{36-38}$ as well as the alloying degree calculated following the technique described by Antolini et al., ${ }^{39,40}$ are reported in Table 3 . The obtained phase cell parameters agree with the values reported in the literature. $^{34,41-43}$ An average crystal size of $(5--8 \pm 1) \mathrm{nm}$, consistent with the STM measurements, was obtained for the different compositions. The calculated alloying degrees for the studied PtRu compositions match those reported in the literature. $^{41}$

3.2. Electrochemical Characterization. 3.2.1. ECSA. Comparison between Methods. The catalysts exhibit welldefined $\mathrm{CO}$ voltammetric stripping peaks with an onset of $\sim 0.35 \mathrm{~V}$ (vs RHE), which is a usual value for PtRu alloys under these conditions. ${ }^{26,44}$ CO-ECSAs are reported in Table 4 for 

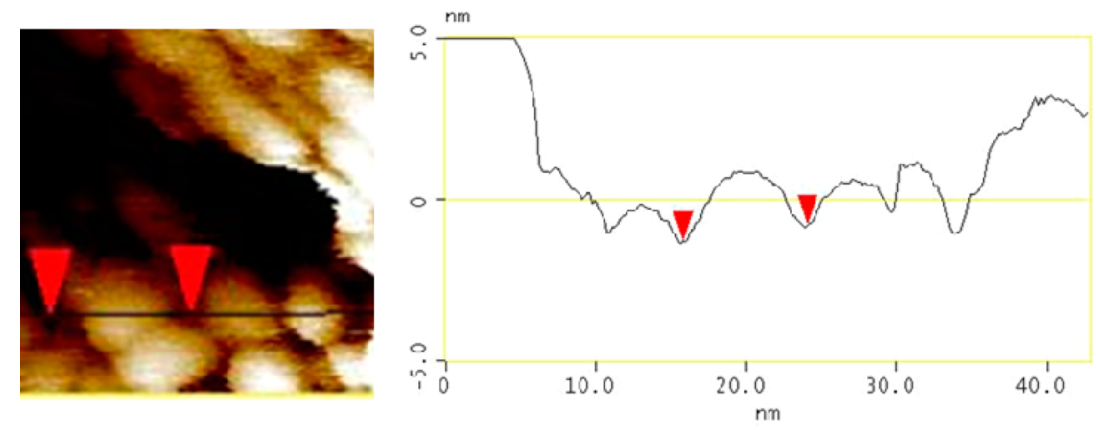

Figure 2. STM image $50 \times 50(x, y) \times 10(z) \mathrm{nm}$ of the electrodeposited mesoporous $\mathrm{Pt}_{0.85} \mathrm{Ru}_{0.15}$ catalyst (left), along with a sectional view (right), where the spherical structure is showed.
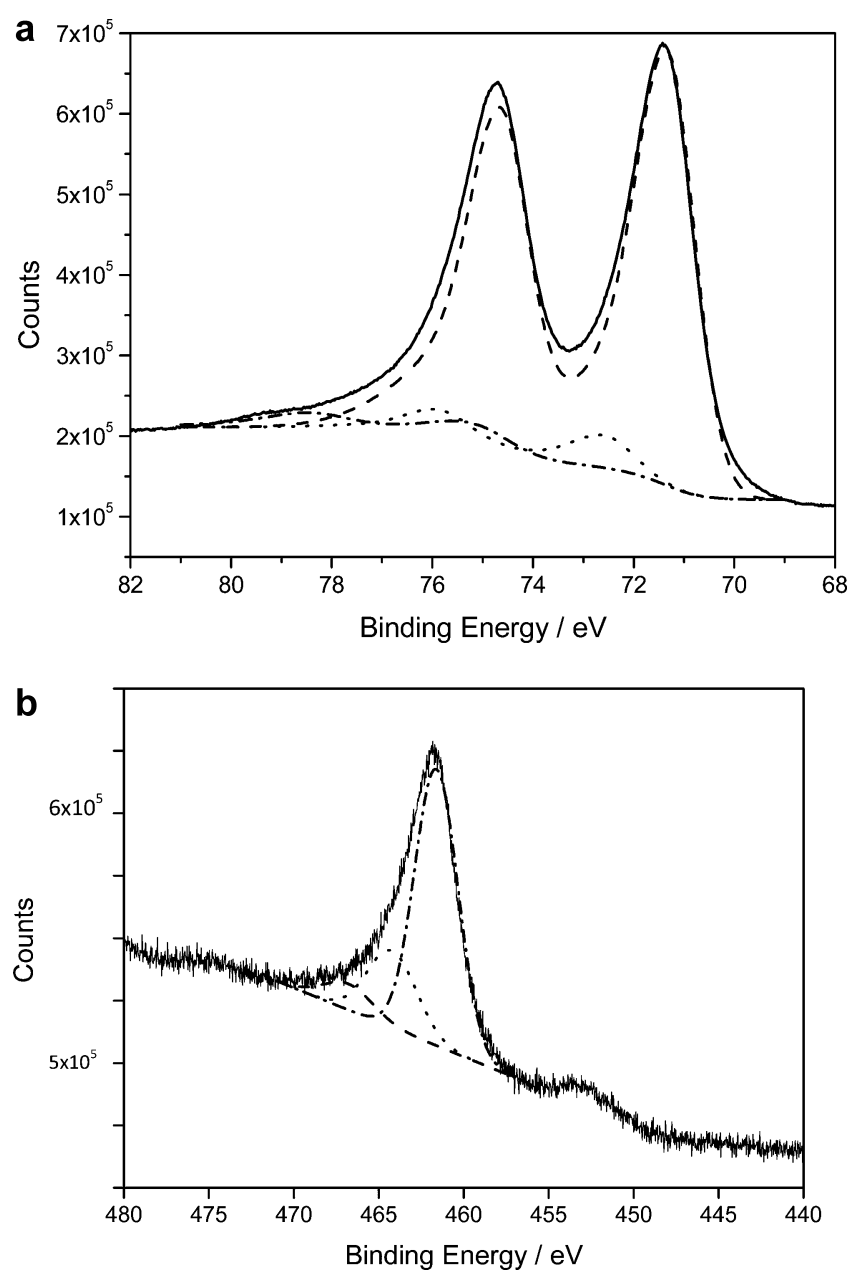

Figure 3. XPS of the mesoporous $\mathrm{Pt}_{0.85} \mathrm{Ru}_{0.15}$ thin film. (a) Pt $4 f \mathrm{XP}$ spectra with the oxides deconvolution areas: (---) metallic $\mathrm{Pt},(\cdots)$ $\mathrm{PtO}$, and (...) $\mathrm{PtO}_{2}$. (b) $\mathrm{Ru} 3 \mathrm{p}_{3 / 2}$ with the oxides deconvolution. (...) metallic $\mathrm{Ru},(\cdots) \mathrm{RuO}_{2}$, and (----) $\mathrm{RuO}_{x} \mathrm{H}_{y}$.

Table 2. Platinum and ruthenium Oxides Compositions (mol \%) of the Synthesized Catalysts Obtained by XPS

$\begin{array}{ccccccc}\text { catalyst } & \mathrm{Pt} & \mathrm{PtO} & \mathrm{PtO}_{2} & \mathrm{Ru} & \mathrm{RuO}_{2} & \mathrm{RuO}_{x} \mathrm{H}_{y} \\ \mathrm{Pt}_{0.97} \mathrm{Ru}_{0.03} & 92.7 & 3 & 4.3 & 73.4 & 13.6 & 13 \\ \mathrm{Pt}_{0.85} \mathrm{Ru}_{0.15} & 91.4 & 5.5 & 3.1 & 65.1 & 16.2 & 18.7 \\ \mathrm{Pt}_{0.65} \mathrm{Ru}_{0.35} & 88.3 & 6.7 & 5 & 70.4 & 22.1 & 7.5 \\ \mathrm{Pt}_{0.50} \mathrm{Ru}_{0.50} & 86.5 & 9.9 & 3.6 & 64.5 & 22.9 & 12.6\end{array}$

Table 3. Lattice Parameters, Particle Size (obtained with the Scherrer's equation), and PtRu Alloy Degree

$\begin{array}{cccc}\text { catalyst } & \text { parameter }(\AA) & \text { particle size }(\mathrm{nm}) & \text { alloy degree } \\ \mathrm{Pt}_{0.97} \mathrm{Ru}_{0.03} & 3.90171 & 5 \pm 1 & 15 \\ \mathrm{Pt}_{0.85} \mathrm{Ru}_{0.15} & 3.90962 & 8 \pm 1 & 9 \\ \mathrm{Pt}_{0.65} \mathrm{Ru}_{0.35} & 3.8994 & 7 \pm 1 & 17\end{array}$

Table 4. H-ECSA and CO-ECSA of the PtRu Catalysts

\begin{tabular}{ccc}
\hline catalyst & H-ECSA $\left(\mathrm{m}^{2} \mathrm{~g}^{-1}\right)$ & CO-ECSA $\left(\mathrm{m}^{2} \mathrm{~g}^{-1}\right)$ \\
$\mathrm{Pt}_{0.97} \mathrm{Ru}_{0.03}$ & 23.5 & 24.8 \\
$\mathrm{Pt}_{0.85} \mathrm{Ru}_{0.15}$ & 27.8 & 23.6 \\
$\mathrm{Pt}_{.65} \mathrm{Ru}_{0.35}$ & 29.0 & 21.0 \\
$\mathrm{Pt}_{0.50} \mathrm{Ru}_{0.50}$ & 23.6 & 19.8 \\
\hline
\end{tabular}

the catalysts, along with the H-ECSAs calculated using the integrated charge in the $\mathrm{H}_{2}$ adsorption/desorption region. It can be observed that the CO-ECSAs are slightly lower that the $\mathrm{H}$-ESCAs, except for the $\mathrm{Pt}_{0.97} \mathrm{Ru}_{0.03}$ catalyst. These differences are consistent with an overestimation of the H-ECSA when subtracting the double layer charge. ${ }^{23,26}$ Nonetheless, all the reported H-ESCAs are similar to the ones shown in previous works for platinum based catalysts obtained via Pluronic F127. This indicates a reasonable reproducibility of the synthesis method. ${ }^{15}$

3.2.2. Chronoamperometric Analysis. The chronoamperometric responses of the mesoporous $\mathrm{Pt} / \mathrm{Ru}$ catalysts at $25{ }^{\circ} \mathrm{C}$ are shown in Figure 4. The rate of current decay is exponential and, at long times, a pseudo steady state is reached. Different electro-catalytic parameters were calculated from the pseudosteady current obtained by chronoamperometry, such as the poisoning rate, $\delta$, the mass activity, $i$, and the current density, $j$.

Poisoning rate and current density values for the prepared mesoporous catalysts are shown in Table 5. Catalysts with more than $15 \% \mathrm{Ru}$ exhibit $\delta$ values that appear to decrease slightly when the atomic fraction of $\mathrm{Ru}$ in the alloys increases. This is consistent with the bifunctional mechanism, in which $\mathrm{Ru}$ prevents the poisoning of $\mathrm{Pt}^{45}$ The low $\delta$ for the $\mathrm{Pt}_{0.97} \mathrm{Ru}_{0.03}$ catalyst may be due to its very low ruthenium content, because $\mathrm{CO}$ is strongly adsorbed on $\mathrm{Pt}^{46}$ However, the observed differences in the $\delta$ values are not significant to suggest a direct relationship with the $\mathrm{Ru}$ content of the mesoporous catalyst.

The poisoning rate found for our mesoporous $\mathrm{Pt} / \mathrm{Ru}$ catalysts, not reported previously in the literature, are comparable to those found for nanoparticulated $\mathrm{PtRu} / \mathrm{C}$ alloys of similar composition. ${ }^{1,3,7}$

Figure 5 shows a comparison of the electrocatalytic performance of our mesoporous catalysts with those of 


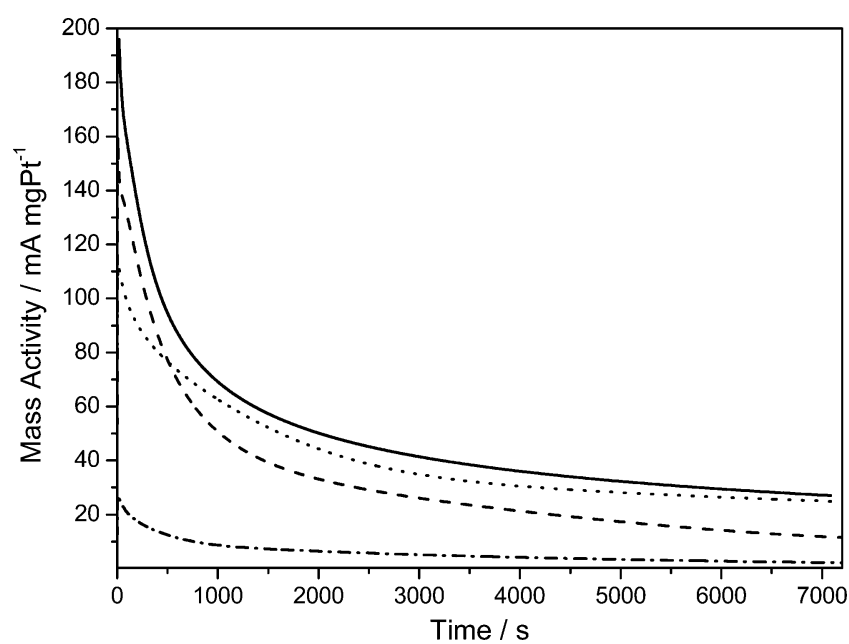

Figure 4. Mass normalized current transients for methanol oxidation in $1 \mathrm{M} \mathrm{CH}_{3} \mathrm{OH}+0.5 \mathrm{M} \mathrm{H}_{2} \mathrm{SO}_{4}$ obtained at $600 \mathrm{mV}$ vs RHE; $\mathrm{Pt}_{0.97} \mathrm{Ru}_{0.03}(---) ; \mathrm{Pt}_{0.85} \mathrm{Ru}_{0.15}(--) ; \mathrm{Pt}_{0.65} \mathrm{Ru}_{0.35}(\cdots)$; and $\mathrm{Pt}_{0.50} \mathrm{Ru}_{0.50}$ $(-)$.

Table 5. Tafel Slope for Methanol Oxidation, Equilibrium Potential, Electron Number, $n, \mathrm{CO}_{2}$ Yield (obtained by DEMS), Poisoning Rate, $\delta$, and Current Density, $j$ (obtained by chronoamperometry)

$\begin{array}{ccccccc}\text { catalyst } & \begin{array}{c}\text { Tafel slope } \\ \left(\mathrm{mV} \mathrm{dec}^{-1}\right)\end{array} & \begin{array}{c}\text { E.P. } \\ (\mathrm{mV})\end{array} & n & \begin{array}{c}\mathrm{CO}_{2} \\ \text { yield }\end{array} & \delta\left(\mathrm{s}^{-1}\right) & \left.\mu \mathrm{A} \mathrm{cm}^{-2}\right) \\ \mathrm{Pt}_{0.97} \mathrm{Ru}_{0.03} & 149.9 & 220 & 0.79 & 53 & 0.017 & 30 \\ \mathrm{Pt}_{0.85} \mathrm{Ru}_{0.15} & 110.7 & 101 & 1.07 & 51 & 0.021 & 48 \\ \mathrm{Pt}_{0.65} \mathrm{Ru}_{0.35} & 118.5 & -35 & 0.99 & 51 & 0.020 & 117 \\ \mathrm{Pt}_{0.50} \mathrm{Ru}_{0.50} & 135.1 & -27 & 0.87 & \text { no data } & 0.018 & 135\end{array}$

${ }^{a}$ Calculated considering the mass activity reported in Figure 4.

nanoparticulated $\mathrm{Pt} / \mathrm{Ru}(\mathrm{NPPtRu})$ catalysts supported on Vulcan, ${ }^{3,21}$ carbon nanotubes (CNT), ${ }^{23,47}$ carbon nanofibers $(\mathrm{CNF}),{ }^{48}$ and also to a smaller mesoporous size catalysts prepared with Brij 56 ( $3 \mathrm{~nm}$ pore diameter), ${ }^{49,50}$ and with Brij $58(7 \mathrm{~nm} \text { pore diameter })^{51}$ with similar composition. Because chronoamperometric studies for the MOR on PtRu catalysts were performed at different periods, some data were compared to $1800 \mathrm{~s}$. and others at $700 \mathrm{~s}$.

It can be observed that our mesoporous catalysts (MPPtRu) exhibit increasing mass activities with increasing $\mathrm{Ru}$ content (in the range $0.03 \leq x \leq 0.50$ ). These activities are higher than those reported for nanoparticulated PtRu (NPPtRu) catalysts supported on Vulcan (carbon black), ${ }^{3,21}$ carbon nanotubes $(\mathrm{CNT}),{ }^{23,47}$ and carbon nanofibers $(\mathrm{CNF})^{48}$ when compared at the same $\mathrm{Ru}$ content.

The comparison of the MOR mass activity of mesoporous PtRu catalysts previously discussed with those of catalysts with small pore size is of relevance. The mesoporous PtRu catalysts with pore size $3 \mathrm{~nm}^{49,50}$ exhibit mass activities 3-4 times lower than the $10 \mathrm{~nm}$ pore size catalysts prepared in this work, for $\mathrm{Ru}$ content between $x=0.04$ and $x=0.50$. A mesoporous $\mathrm{Pt}_{0.95} \mathrm{Ru}_{0.05}$ catalyst with an intermediate pore size $(7 \mathrm{~nm})^{51}$ seems to have a higher mass activity than the catalysts with 3 $\mathrm{nm}$ pore size, and similar to our mesoporous $\mathrm{Pt}_{0.85} \mathrm{Ru}_{0.15}$ catalyst with $10 \mathrm{~nm}$ pore size. However, it is not possible to estimate if a higher $\mathrm{Ru}$ contents for the $7 \mathrm{~nm}$ pore size mesoporous catalyst could achieve higher mass activities than the reported in this work for mesoporous $\mathrm{Pt}_{0.50} \mathrm{Ru}_{0.50}$.

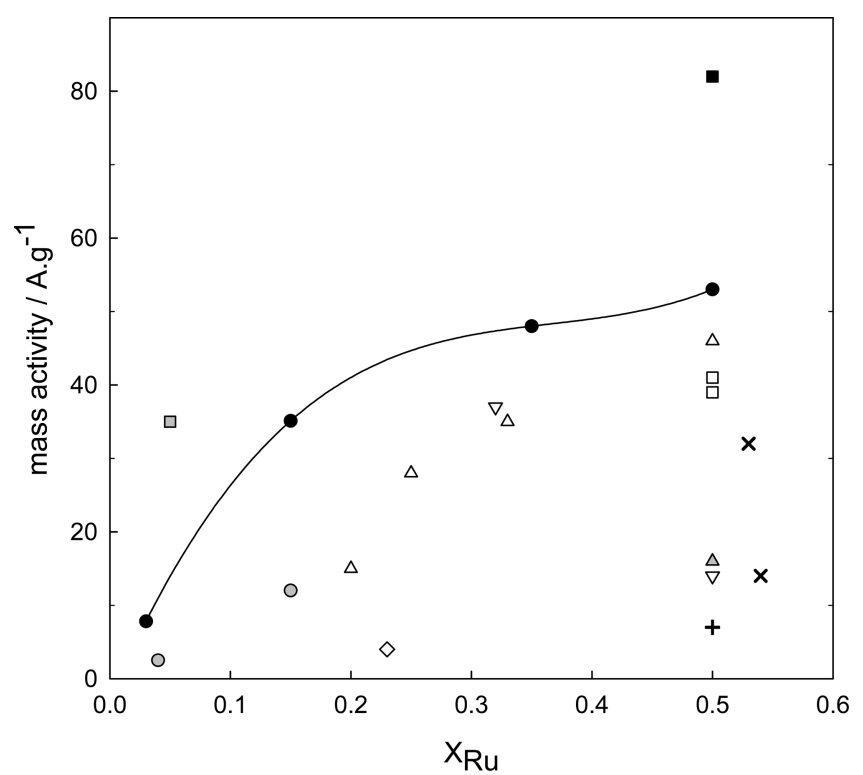

Figure 5. Mass activity for $\mathrm{MOR}$ in $\mathrm{H}_{2} \mathrm{SO}_{4}$ (aq) obtained by chronoamperometry: MPPtRu in $1 \mathrm{M} \mathrm{CH}_{3} \mathrm{OH}$, at $0.6 \mathrm{~V}$ vsRHE, 25 ${ }^{\circ} \mathrm{C}, t=1800 \mathrm{~s}(\bullet)$ and $t=700 \mathrm{~s}(\boldsymbol{\square})$ (this work); (+) PtRu ETEK, in 1 $\mathrm{M} \mathrm{CH} \mathrm{C}_{3} \mathrm{OH}$, at $0.6 \mathrm{~V}$ vsRHE, $25^{\circ} \mathrm{C}, t=1800 \mathrm{~s}^{21}(\nabla) \mathrm{NPPtRu} /$ Vulcan, in $1 \mathrm{M} \mathrm{CH}_{3} \mathrm{OH}$, at $0.6 \mathrm{~V}$ vs RHE, $25{ }^{\circ} \mathrm{C}, t=1800 \mathrm{~s}^{21}(\Delta)$ $\mathrm{NPPtRu} /$ Vulcan, in $2 \mathrm{M} \mathrm{CH}_{3} \mathrm{OH}$, at $0.4 \mathrm{~V}$ vs RHE, $t=1800 \mathrm{~s}$, temperature not indicated; ${ }^{3}(\square) \mathrm{NPPtRu} / \mathrm{CNT}$, in $1 \mathrm{M} \mathrm{CH}_{3} \mathrm{OH}$, at $0.4 \mathrm{~V}$ vsRHE, $t=1800 \mathrm{~s}$, temperature not indicated ${ }^{23}$; $(\diamond) \mathrm{NPPtRu} /$ $\mathrm{CNT}$, in $2 \mathrm{M} \mathrm{CH}_{3} \mathrm{OH}$, at $0.5 \mathrm{~V}$ vsRHE, $25^{\circ} \mathrm{C}, t=1800 \mathrm{~s}^{55}$ (gray circle symbol) MPPtRu (unsupported), in $0.5 \mathrm{M} \mathrm{CH}_{3} \mathrm{OH}$, at $0.5 \mathrm{~V}$ vsRHE, and $60{ }^{\circ} \mathrm{C}$ (time not indicated); ${ }^{49}$ (gray square symbol) MPPtRu in $0.5 \mathrm{M} \mathrm{CH}_{3} \mathrm{OH}$, at $0.6 \mathrm{~V}$ vsRHE, $t=1800 \mathrm{~s}$, temperature not indicated; ${ }^{51}(\times) \mathrm{NPPtRu} / \mathrm{CNF}$ in $2 \mathrm{M} \mathrm{CH}_{3} \mathrm{OH}$, at $0.5 \mathrm{~V}$ vs RHE, $t=700 \mathrm{~s}^{48}$ (gray triangle symbol) $\mathrm{MPPtRu} / \mathrm{CNF}$ in $1 \mathrm{M} \mathrm{CH}_{3} \mathrm{OH}$, at $0.55 \mathrm{~V}$ vsRHE, $t=700 \mathrm{~s}^{50}$

The results of MOR efficiency along with the results of DEMS analysis will be discussed in section 3.2.5.

3.2.3. Tafel Analysis. The MOR mechanism was investigated through the analysis of the Tafel slopes obtained by linear sweep voltammograms at potentials between 0.45 and $0.65 \mathrm{~V}$ (vs RHE, scanning rate: $5 \mathrm{mV} \mathrm{s}^{-1}$ ).

According to the bifunctional model of methanol electrooxidation, ${ }^{45,52}$ the discharge of water occurs on the $\mathrm{Ru}$ sites with the formation of $\mathrm{Ru}-\mathrm{OH}$ groups on the catalyst surface. This step, considered by many authors ${ }^{53,54}$ as the rate determining one, requires the transfer of one electron and occurs at overpotentials between $0.45-0.65 \mathrm{~V}$ vs RHE. ${ }^{55,56}$ Thus, the methanol dehydrogenation in the low potential range, where the $\mathrm{CO}$ oxidation may be affected by the number of neighbors $\mathrm{Ru}$ sites, ${ }^{57}$ is similar for all the catalysts.

The mechanism proposed by Abruña and coworkers for the oxidation of methanol on polycrystalline $\mathrm{Pt}^{58}$ and on $\mathrm{Pt} / \mathrm{Ru}^{33}$ considers two one-electron $(n=1)$ processes. These are the first deprotonation of methanol to form $\mathrm{Pt}-\mathrm{CH}_{2} \mathrm{OH}$ (or Pt$\mathrm{CH}_{3} \mathrm{O}$ ), and the water deprotonation to give $\mathrm{Ru}-\mathrm{OH}$ plus $\mathrm{H}^{+}$, which occurs at more oxidative potentials that the former process and it has a clear dependence with the ruthenium content of the alloy. ${ }^{55}$

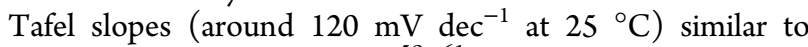
those reported in the literature, ${ }^{59-61}$ were obtained for all the catalysts (see Table 5). If a transfer coefficient $\alpha \approx 0.5$ is assumed, the Tafel slopes indicate that the rate determining step corresponds to the transference of one electron. This 
indicates that it could be any of the two one-electron processes above mentioned. ${ }^{62}$

In Table 5 it can be observed a shift of the Equilibrium Potential (E.P.) to more reductive values with increasing $\mathrm{Ru}$ in the alloy. This effect is more noticeable when the $\mathrm{Ru}$ atomic fraction goes from 0.03 to 0.35 , whereas it is negligible between 0.35 and 0.50 . A plausible explanation would be that for $\mathrm{Ru}$ atomic fractions lower than 0.35 , the rate determining step is the deprotonation of water to form $\mathrm{Ru}-\mathrm{OH}$. For higher $\mathrm{Ru}$ contents the rate determining step is the methanol deprotonation on $\mathrm{Pt}$ nuclei, a process that predominates at more reductive potentials.

3.2.3. Activation Energy. Activation energies for positiveand negative-going sweeps were calculated from the data obtained by CVs at $10 \mathrm{mV} \mathrm{s}^{-1}$, between 0 and $800 \mathrm{mV}$ (vs $\mathrm{RHE}$ ), at different temperatures from 5 to $45^{\circ} \mathrm{C}$, with steps of $5{ }^{\circ} \mathrm{C}$. The state of the surface (surface oxidation, adsorption of species, and degree of coverage of semioxidized reaction intermediates) is different for positive- and negative-going sweeps, which explains the observed differences in the apparent activation energy.

Figure 6 shows the potential dependence of the activation energies for positive- and negative-going sweeps for $\mathrm{Pt}_{0.85} \mathrm{Ru}_{0.15}$

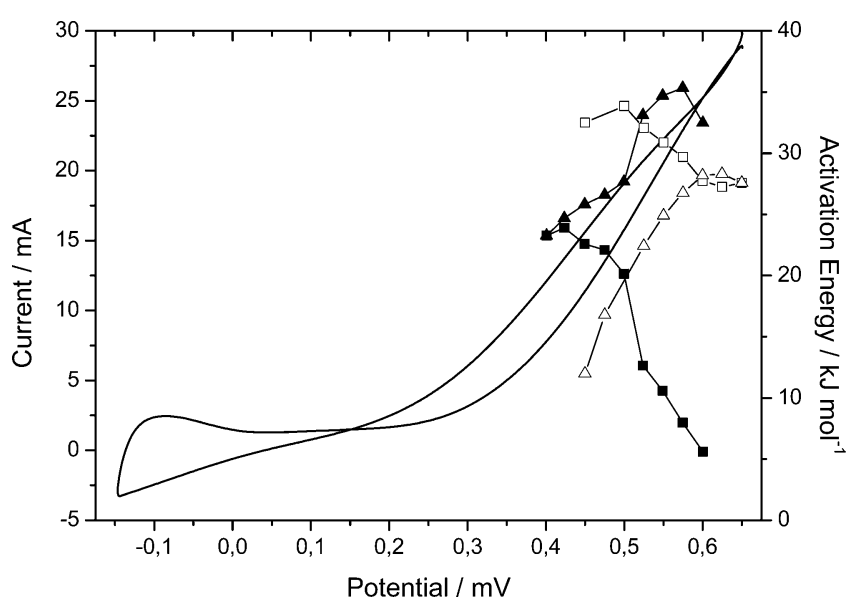

Figure 6. $\mathrm{CV}$ for $\mathrm{Pt}_{0.65} \mathrm{Ru}_{0.35}\left(25^{\circ} \mathrm{C}, 1 \mathrm{M}\right.$ methanol) and activation energy dependence with the applied potential for: $(\boldsymbol{\Delta}) \mathrm{Pt}_{0.65} \mathrm{Ru}_{0.35}$ positive-going sweep, $(\Delta) \mathrm{Pt}_{0.85} \mathrm{Ru}_{0.15}$ positive-going sweep, ( $\square$ ) $\mathrm{Pt}_{0.85} \mathrm{Ru}_{0.15}$ negative-going sweep, (ם) $\mathrm{Pt}_{0.65} \mathrm{Ru}_{0.35}$ negative-going sweep.

and $\mathrm{Pt}_{0.65} \mathrm{Ru}_{0.35}$ along with an example of cyclic voltammetry for $\mathrm{Pt}_{0.65} \mathrm{Ru}_{0.35}\left(25{ }^{\circ} \mathrm{C}\right.$, $1 \mathrm{M}$ methanol, $\left.10 \mathrm{mV} \mathrm{s}^{-1}\right)$. This figure illustrates that increasing the $\mathrm{Ru}$ content in the catalyst increases the positive-going activation energies. This may be due to electronic changes in the surface originated by the presence of ruthenium oxides, as described in the previous section.

It is observed that the activation energy in the negative-going scan decreases considerably by increasing the $\mathrm{Ru}$ content in the catalyst. This would be due to an increase in the amount of oxygen surface groups, which facilitate the formation of $\mathrm{CO}_{2}$ from $\mathrm{CO}$ adsorbed on $\mathrm{Pt}$, avoiding poisoning the surface.

Changes in the activation energy for positive and negative scans can be attributed to the different products of oxidation of methanol adsorbed on the catalyst surface (such as $\mathrm{Pt}_{-} \mathrm{CH}_{3} \mathrm{O}$, $\mathrm{Pt}-\mathrm{CH}_{2} \mathrm{OH}, \mathrm{Pt}-\mathrm{COOH}$, etc.), and also to the oxidation (and reduction) of the surface atoms on the catalyst. ${ }^{59}$
The activation energies measured in this work are significantly lower than those reported in the literature for $\mathrm{Pt}^{58}$ (between 26 and $76 \mathrm{~kJ} \mathrm{~mol}^{-1}$, depending of the potential applied in the positive-going sweep, in $0.5 \mathrm{M}$ methanol/0.1 M $\mathrm{H}_{2} \mathrm{SO}_{4}$ solution) and $\mathrm{PtRu}$ alloys $\left(41.9 \mathrm{~kJ} \mathrm{~mol}^{-1}\right.$ for $\mathrm{Pt}_{0.53} \mathrm{Ru}_{0.47} / \mathrm{CNT}$, and $46 \mathrm{~kJ} \mathrm{~mol}{ }^{-1}$ for $\mathrm{Pt}_{0.69} \mathrm{Ru}_{0.31} / \mathrm{CNT}$ obtained as an average of the values measured at 0.4 and 0.5 $\mathrm{V}$ in $2 \mathrm{M}$ methanol/1 $\mathrm{M} \mathrm{H}_{2} \mathrm{SO}_{4}$ solution). ${ }^{59}$

The activation energies measured for the $\mathrm{Pt}_{0.50} \mathrm{Ru}_{0.50}$ catalyst, not shown in Figure 7, are very similar to that of $\mathrm{Pt}_{0.65} \mathrm{Ru}_{0.35}$, a

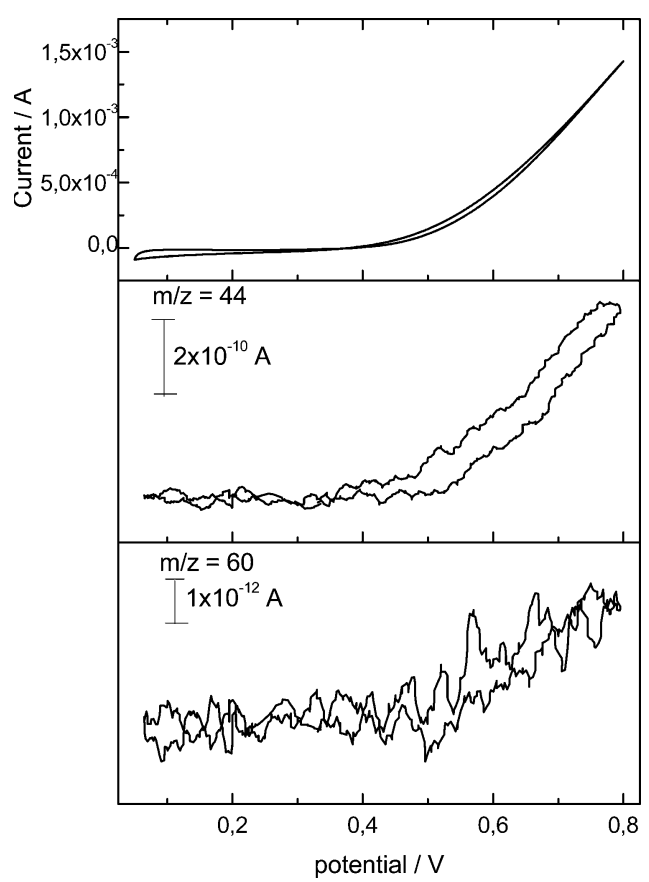

Figure 7. CVs and MSCVs for $\mathrm{CO}_{2}(m / z=44)$ and methyl formate $(\mathrm{m} / z=60)$ formed during methanol electrooxidation of $1 \mathrm{M}$ $\mathrm{CH}_{3} \mathrm{OH} / 1 \mathrm{M} \mathrm{H}_{2} \mathrm{SO}_{4}$ on $\mathrm{Pt}_{0.65} \mathrm{Ru}_{0.35}$ at $25{ }^{\circ} \mathrm{C}$. Scan rate $=5 \mathrm{mV} \mathrm{s}^{-1}$.

behavior that can be explained by resorting to the Tafel analysis in section 3.2.3. For catalysts with $\mathrm{Ru}$ atomic fraction higher than 0.35, methanol deprotonation on $\mathrm{Pt}$ nuclei is the rate determining step and this process would have an activation energy independent on the $\mathrm{Ru}$ content of the catalyst.

3.2.4. DEMS. Figure 7 shows the cyclic voltammograms $(\mathrm{CVs})$ and the mass spectrometry cyclic voltammograms (MSCVs) for $\mathrm{CO}_{2}(\mathrm{~m} / z=44)$ and $\mathrm{HCO}_{2} \mathrm{H}(\mathrm{m} / z=60)$ formed during the methanol oxidation on mesoporous $\mathrm{Pt}_{0.85} \mathrm{Ru}_{0.15}$ catalyst. The $\mathrm{CO}_{2}$ conversion efficiency for all the mesoporous catalysts was around $51-53 \%$ (with an error below $3.5 \%)$ at $25{ }^{\circ} \mathrm{C}$. This behavior is similar to that observed for carbon supported $\mathrm{Pt} / \mathrm{Ru}$ catalysts, ${ }^{63}$ although Abruña and coworkers ${ }^{58}$ have found $\mathrm{CO}_{2}$ conversion efficiency between 40 and $80 \%$, for $\mathrm{PtRu} / \mathrm{C}$ E-TEK and $\mathrm{Ru}$-decorated $\mathrm{Pt}$ catalysts depending on the acid concentration and catalyst load. The byproducts in the methanol oxidation are soluble and less volatile species, such as formic acid and formaldehyde, which are not quantified in our DEMS study.

Garcia et al. ${ }^{50}$ performed a detailed DEMS study of $\mathrm{Pt} / \mathrm{Ru}$ catalysts with mesoporous of size $\sim 3 \mathrm{~nm}$, prepared using Brij 56 as a template, and reported a $\mathrm{CO}_{2}$ conversion efficiency of $37 \%$. Thus, the catalysts electrodeposited using the F127 template with mesoporous size $\sim 10 \mathrm{~nm}$ exhibit a $14 \%$ absolute enhancement of the $\mathrm{CO}_{2}$ conversion (or a relative increment of 
$38 \%)$. This significant result would indicate that the higher MOR mass activity of the mesoporous catalyst with larger pore sizes could be linked to its higher $\mathrm{CO}_{2}$ conversion efficiency.

3.2.5. Effect of Pore Size on the MOR Activity of PtRu Mesoporous Catalysts. The activity differences between mesoporous catalysts with pore size of 3 and $10 \mathrm{~nm}$ can be qualitatively explained by resorting to simple calculations, which considers the structural features of these materials. For a $3 \mathrm{~nm}$ cylindrical pore catalyst the ratio $A_{\text {in }} / A_{\text {ext }}$ between the internal area of the pores to the external area of the spherical particles of catalyst (as shown in Fig 1) is 2.6. This means that, an important fraction of the catalytic area is internal. On the other hand, $A_{\text {in }} / A_{\text {ext }} \approx 0.75$, for a catalyst with $10 \mathrm{~nm}$ pores, meaning that the external area is predominant. These results explain the differences observed between the ECSA of our Pluronic-based catalyst $\left(24-29 \mathrm{~m}^{2} \mathrm{~g}^{-1}\right)$ and the Brij-based catalyst $\left(47 \mathrm{~m}^{2} \mathrm{~g}^{-1}\right)$ reported by Pastor et al. ${ }^{30}$ The calculated ECSA of both catalysts would be close to $17 \mathrm{~m}^{2} \mathrm{~g}^{-1}$ if the internal area of the mesoporous catalyst is not taken into account.

The oxidation rate of methanol on the internal catalyst surface is determined by its diffusion though the pores, and it should be faster in the $10 \mathrm{~nm}$ than in the $3 \mathrm{~nm}$ pores. It is reasonable to assume that most of the methanol in the $3 \mathrm{~nm}$ pore catalyst oxidizes on the external surface of the catalyst particles, where the methanol residence time is not enough to yield a high $\mathrm{CO}_{2}$ conversion. On the contrary, a higher fraction of methanol could enter the $10 \mathrm{~nm}$ pores and would convert to $\mathrm{CO}_{2}$ more efficiently, due to a longer residence time. However, because of the fact that the volume of the pores accounts for only a small fraction (less than 20\%) of the total volume of methanol solution, the differences in $\mathrm{CO}_{2}$ conversion are not as significant as expected when the different mass activities (reported in Figure 6) are taken into account.

It is worth to mention that the formation of $\mathrm{CO}_{2}$ in the pores of our catalyst would not result in the formation of bubbles, which could prevent the reflux of fresh methanol to the pore surface. A calculation of the $\mathrm{CO}_{2}$ supersaturation in pores of 10 $\mathrm{nm}$ indicates ${ }^{64}$ that it could be as high as 123 bar. That is, $\mathrm{CO}_{2}$ would remain in the liquid phase inside the pores, as well as in the mesoporous channels (40-60 nm diameter) surrounding the spherical catalyst particles (see Figure 1).

Other catalyst features, such as the structural properties, particle size, curvature radius, exposed crystallographic faces, etc., are probably affected by the template modification, which in turns leads to an improvement in the catalyst efficiency. Chrzanowski and Wieckowski ${ }^{46}$ have found that the catalytic activity of $\mathrm{Pt} / \mathrm{Ru}$ catalysts toward MOR is maximized by the presence of (111) crystallographic faces, while the CO formation from methanol is lower on the (111) face than on the other faces. ${ }^{46,62}$ The analysis of the correlation between single-crystal faces and catalytic activity is not the purpose of this study and will be the subject of forthcoming work.

\section{CONCLUSIONS}

Mesoporous $\mathrm{Pt} / \mathrm{Ru}$ catalysts with large pore hexagonal 2D structures were successfully synthesized using a Pluronic F127 template. The electrochemical characterization shows that these catalysts have a high activity for the MOR. The measured activation energies consistently decreases as the ruthenium content is increased. Furthermore, a change in the equilibrium potential is observed when the ruthenium content is increased. These observations indicate a change in the rate-determining step as the $\mathrm{Ru}$ content of the catalyst increases, presumably because of changes in the electronic structure of the catalyst.

The $\mathrm{Pt} / \mathrm{Ru}$ mesoporous catalysts prepared in this work were found to have higher methanol to $\mathrm{CO}_{2}$ conversion efficiencies than those mesoporous catalysts with smaller pore diameter, and similar to conventional nanosized catalysts supported on carbon substrates. As the pore size increases, the accessibility of methanol to the catalyst is favored, increasing the methanol residence time and enhancing its conversion efficiency to $\mathrm{CO}_{2}$.

In summary, the procedure described in this work for preparing mesoporous $\mathrm{Pt} / \mathrm{Ru}$ catalyst by electrodeposition using Pluronic F127 block copolymer as a template provides a method for the generation of high-performance anodes for $\mu \mathrm{DMFC}$.

\section{AUTHOR INFORMATION}

\section{Corresponding Author}

*E-mail: hrcorti@cnea.gov.ar. Tel.: (5411) 67727174. Fax: (5411) 67727121.

\section{Notes}

The authors declare no competing financial interest.

\section{ACKNOWLEDGMENTS}

The authors thank Agencia Nacional de Promoción Científica y Tecnológica (PICT 2097, PAE 36985), and CONICET (PIP 00095) for financial support. H.R.C., M.M.B., F.J.W., and F.A.V. are permanent research fellows of CONICET. E.A.F. thanks CONICET for a graduate fellowship. We also thank Jaime Flomenbaum (City University of New York) by helping us to improve this manuscript.

\section{REFERENCES}

(1) Bruno, M. M.; Franceschini, E. A.; Planes, G. A.; Corti, H. R. J. Appl. Electrochem. 2009, 40, 257-263.

(2) Sieben, J. M.; Duarte, M. M. E.; Mayer, C. E. Int. J. Hydrogen Energy 2010, 35, 2018-2024.

(3) Guo, J. W.; Zhao, T. S.; Prabhuram, J.; Chen, R.; Wong, C. W. Electrochim. Acta 2005, 51, 754-763.

(4) Attard, G. S.; Bartlett, P. N.; Coleman, N. R. B.; Elliott, J. M.; Owen, J. R.; Wang, J. H. Science 1997, 278, 838-840.

(5) Cui, X.; Shi, J.; Zhang, L.; Ruan, M.; Gao, J. Carbon 2009, 47, 186-194.

(6) Kim, H.; Kim, P.; Joo, J. B.; Kim, W.; Song, I. K.; Yi, J. J. Power Sources 2006, 157, 196-200.

(7) Kucernak, A.; Jiang, J. Chem. Eng. J. 2003, 93, 81-90.

(8) Attard, G. S.; Leclerc, S. A. A.; Maniguet, S.; Russell, A. E.; Nandhakumar, I.; Bartlett, P. N. Chem. Mater. 2001, 13, 1444-1446.

(9) Elliott, J. M.; Attard, G. S.; Bartlett, P. N.; Coleman, N. R. B.; Merckel, D. A. S.; Owen, J. R. Chem. Mater. 1999, 11, 3602-3609.

(10) Attard, G. S.; Goltner, C. G. Porous metal and method of preparation thereof. Patent WO1998037997 A3, Dec 17, 1998.

(11) Attard, G. S.; Bartlett, P. N.; Coleman, N. R. B.; Elliott, J. M.; Owen, J. R. Langmuir 1998, 14, 7340-7342.

(12) Takahashi, R.; Sato, S.; Sodesawa, T.; Nishida, H. J. Ceram. Soc. Jpn. 2001, 109, 840-845.

(13) Takahashi, R.; Sato, S.; Sodesawa, T.; Nishida, H. Phys. Chem. Chem. Phys. 2002, 4, 3800-3805.

(14) Takahashi, R.; Sato, S.; Sodesawa, T.; Kamomae, Y. Phys. Chem. Chem. Phys. 2000, 2, 1199-1204.

(15) Franceschini, E. A.; Planes, G. A.; Williams, F. J.; Soler-Illia, G. J. A. A.; Corti, H. R. J. Power Sources 2011, 196, 1723-1729.

(16) Alexandridis, P.; Hatton, T. A. Colloids Surf., A 1995, 96, 1-46.

(17) Zhao, D. Y.; Huo, Q. S.; Feng, J. L.; Chmelka, B. F.; Stucky, G. D. J. Am. Chem. Soc. 1998, 120, 6024-6036. 
(18) Zhao, D. Y.; Sun, J. Y.; Li, Q. Z; Stucky, G. D. Chem. Mater. 2000, 12, 275-279.

(19) Zhang, F. Q.; Yan, Y.; Yang, H. F.; Meng, Y.; Yu, C. Z.; Tu, B.; Zhao, D. Y. J. Phys. Chem. B 2005, 109, 8723-8732.

(20) Yu, C. Z.; Fan, J.; Tian, B. Z.; Zhao, D. Y.; Stucky, G. D. Adv. Mater. 2002, 14, 1742-1745.

(21) Sivakumar, P.; Tricoli, V. Electrochim. Acta 2006, 51, 12351243.

(22) Viva, F. A.; Bruno, M. M.; Jobbágy, M.; Corti, H. R. J. Phys. Chem. C 2012, 116, 4097-4104.

(23) Prabhuram, J.; Zhao, T. S.; Liang, Z. X.; Chen, R. Electrochim. Acta 2007, 52, 2649-2656.

(24) Franceschini, E. A.; Bruno, M. M.; Viva, F. A.; Williams, F. J.; Jobbágy, M.; Corti, H. R. Electrochim. Acta 2012, 71, 173-180.

(25) Bruno, M. M.; Franceschini, E. A.; Viva, F. A.; Thomas, Y. R. J.;

Corti, H. R. Int. J. Hydrogen Energy 2012, 37, 14911-1491.

(26) La-Torre-Riveros, L.; Guzman-Blas, R.; Méndez-Torres, A.E.; Prelas, M.; Tryk, D.A.; Cabrera, C.R. ACS Appl. Mater. Interfaces 2012, 4, 1134-1147.

(27) Jiang, J.; Kucernak, A. J. Electroanal. Chem. 2003, 543, 187-199.

(28) Trasatti, S.; Petrii, O. A. Pure Appl. Chem. 1991, 63, 711-734.

(29) Paganin, V. A.; Sitta, E.; Iwasita, T.; Vielstich, W. J. Appl. Electrochem. 2005, 35, 1239-1243.

(30) Pastor, E.; Planes, G. A.; García, G. Electrochem. Commun. 2007, 9, 839-843.

(31) Jusys, Z.; Kaiser, J.; Behm, R. J. Langmuir 2003, 19, 6759-6769.

(32) Baltruschat, H. J. Am. Soc. Mass Spectrom. 2004, 15, 1693-1706.

(33) Wang, H.; Alden, L. R.; Di Salvo, F. J.; Abruña, H.D. Langmuir 2009, 25, 7725-7735.

(34) Lewera, A.; Zhou, W. P.; Vericat, C.; Chung, J. H.; Haasch, R.; Wieckowski, A.; Bagus, P. S. Electrochim. Acta 2006, 51, 3950-3956.

(35) Shukla, A. K.; Neergat, M.; Bera, P.; Jayaram, V.; Hegde, M. S. J. Electroanal. Chem. 2001, 504, 111-119.

(36) Li, W. Z.; Zhou, W. Z.; Li, H. Q.; Zhou, Z. H.; Zhou, B.; Sun, J. Q.; Xin, Q. Electrochim. Acta 2004, 49, 1045-1055.

(37) Tian, Z. Q.; Jiang, S. P.; Liang, Y. M.; Shen, P. K. J. Phys. Chem. B 2006, 110, 5343-5350.

(38) Hou, Z.; Yi, B.; Yu, H.; Lin, Z.; Zhang, H. J. J. Power Sources 2003, 123, 116-125.

(39) Antolini, E.; Cardellini, F. J. Alloys Compd. 2001, 315, 118-122.

(40) Antolini, E.; Giorgi, L.; Cardellini, F.; Passalacqua, E. J. Solid State Electrochem. 2001, 5, 131-140.

(41) Liu, Z.; Su, F.; Zhang, X.; Tay, S.W. ACS Appl. Mater. Interfaces 2011, 3, 3824-3830.

(42) Ma, L.; Liu, C.; Liao, J.; Lu, T.; Xing, W.; Zhang, J. Electrochim. Acta 2009, 54, 7274-7279.

(43) Aricó, A. S.; Antonucci, P. L.; Modica, E.; Baglio, V.; Kim, H.; Antonucci, V. Electrochim. Acta 2002, 47, 3723-3732.

(44) Maillard, F.; Lu, G.-Q.; Wieckowski, A.; Stimming, U. J. Phys. Chem. B 2005, 109, 16230-16243.

(45) Watanabe, M.; Motoo, S. J. Electroanal. Chem. 1975, 60, 267274.

(46) Chrzanowski, W.; Wieckowski, A. Langmuir 1998, 14, 19671970.

(47) Li, L.; Xing, Y. Energies 2009, 2, 789-804.

(48) Sebastián, D.; Suelves, I.; Pastor, E.; Moliner, R.; Lázaro, M. J. Appl. Catal., B 2013, 132-133, 13-21.

(49) Takai, A.; Saida, T.; Sugimoto, W.; Wang, L.; Yamauchi, Y.; Kuroda, K. Chem. Mater. 2009, 21, 3414-3423.

(50) García, G.; Florez-Montaño, J.; Hernandez-Creus, A.; Pastor, E.; Planes, G. A. J. Power Sources 2010, 196, 2979-2986.

(51) Wang, H.; Imura, M.; Remoto, Y.; Wang, L.; Jeong, H. Y.; Yokoshima, T.; Terasaki, O.; Yamauchi, Y. Chem.-Eur. J. 2012, 18, $13142-13148$.

(52) Ticianelli, E.; Berry, J. G.; Paffet, M. T.; Gottesfeld, S. J. Electroanal. Chem. 1977, 81, 229-238.

(53) Zhu, Y.; Uchida, H.; Yajima, T.; Watanabe, M. Langmuir 2001, 17, 146-154.
(54) Umeda, M.; Kokubo, M.; Mohamedi, M.; Uchida, I. Electrochim. Acta 2003, 48, 1367-1374.

(55) Iwasita, T. Electrochim. Acta 2002, 47, 3663-3674.

(56) Kashima, K.; Umeda, M.; Yamada, A.; Uchida, I. Electrochemistry 2006, 74, 166-168.

(57) Gasteiger, H. A.; Markovic, N.; Ross, P. N.; Cairns, E. J. J. Phys. Chem. 1993, 97, 12020-12029.

(58) Cohen, J. L.; Volpe, D. J.; Abruña, H. D. Phys. Chem. Chem. Phys. 2007, 9, 49-77.

(59) Roth, C.; Marty, N.; Hahn, F.; Leger, J. M.; Lamy, C.; Fuess, H. J. Electrochem. Soc. 2002, 149, 433-439.

(60) Meli, G.; Leger, J. M.; Lamy, C. J. Appl. Electrochem. 1993, 23, $197-202$.

(61) Inada, R.; Shimazu, K.; Kita, H. J. Electroanal. Chem. 1990, 277, $315-326$.

(62) Wang, H.; Wingender, C.; Baltruschat, H.; Lopez, M.; Reetz, M. T. J. Electroanal. Chem. 2001, 509, 163-169.

(63) Nordlund, J.; Roessler, A.; Lindbergh, G. J. Appl. Electrochem.. 2002, 32, 259-265.

(64) Herrero, E.; Franaszczuk, K.; Wieckowski, A. J. Phys. Chem. 1994, 98, 5074-5083. 